\title{
Pathogenesis of Bovine alphaherpesvirus 2 in calves following different routes of inoculation ${ }^{1}$
}

\author{
Bruna P. Amaral ${ }^{2,3}$, José C. Jardim ${ }^{4}$ (D), Juliana F. Cargnelutti ${ }^{3,5}$, \\ Mathias Martins $^{6,7}$ (D), Rudi Weiblen ${ }^{2,3}$ and Eduardo F. Flores ${ }^{2,3 *}$ (D)
}

\begin{abstract}
Amaral B.P., Jardim J.C., Cargnelutti J.F., Martins M., Weiblen R. \& Flores E.F. 2020. Pathogenesis of Bovine alphaherpesvirus 2 in calves inoculated by different routes. Pesquisa Veterinária Brasileira 40(5):360-367. Setor de Virologia, Departamento de Medicina Veterinária Preventiva, Universidade Federal de Santa Maria, Av. Roraima 1000, Rua Z, Prédio 63A, Santa Maria, RS 97105-900, Brazil. E-mail: eduardofurtadoflores@gmail.com

Bovine alphaherpesvirus 2 (BoHV-2) is the agent of herpetic mammilitis (BHM), a cutaneous and self-limiting disease affecting the udder and teats of cows. The pathogenesis of BoHV-2 is pourly understood, hampering the development of therapeutic drugs, vaccines and other control measures. This study investigated the pathogenesis of BoHV-2 in calves after inoculation through different routes. Three- to four-months seronegative calves were inoculated with BoHV-2 $\left(10^{7} \mathrm{TCID}_{50} \mathrm{~mL}^{-1}\right)$ intramuscular (IM, $\left.\mathrm{n}=4\right)$, intravenous (IV, $\mathrm{n}=4$ ) or transdermal (TD) after mild scarification $(n=4)$ and submitted to virological, clinical and serological monitoring. Calves inoculated by the IV route presented as light increase in body temperature between days 6 to 9 post-inoculation (pi). Virus inoculation by the TD route resulted in mild inflammatory lesions at the sites of inoculation, characterized by hyperemia, small vesicles, mild exudation and scab formation, between days 2 and 8pi. Virus or viral DNA was detected by PCR in the crusts/swabs collected from lesions of 3 out of 4 animals inoculated TD from day 2 to 8pi. Viremia was detected in $3 / 4$ animals of the IM group (from day 4 to 8 pi); in $2 / 4$ animals of the IV group (days 6 and 8 pi) but not in the TD group. Calves from all inoculated groups seroconverted to BoHV-2 in titers from 4 to 64 , as indicated by virus-neutralizing (VN) assays performed in sera collected at day 15pi. Administration of dexamethasone (Dex) to the inoculated calves at day 48pi, did not result in virus reactivation as indicated by lack of virus detection in the blood and/or in inoculation sites and no increase in VN antibody titers. These results demonstrated that BoHV-2 was able to replicate efficiently in calves following different routes of exposure, produced viremia after IM and IV inoculation and was not reactivated by Dex treatment.
\end{abstract}

INDEX TERMS: Pathogenesis, Bovine alphaherpesvirus 2, calves, cattle, acute infection, latency.

RESUMO.- [Patogênese do alfaherpesvírus bovino 2 em bezerros inoculados por diferentes vias.] 0 alfaherpesvírus bovino 2 (BoHV-2) é um agente etiológico da mamilite herpética (BHM), uma doença cutânea e autolimitante do

\footnotetext{
${ }^{1}$ Received on February 19, 2020.

Accepted for publication on March 6, 2020.

${ }^{2}$ Setor de Virologia, Departamento de Medicina Veterinária Preventiva, Universidade Federal de Santa Maria (UFSM), Av. Roraima 1000, Prédio 63A, Santa Maria, RS 97105-900, Brazil. *Corresponding author: eduardofurtadoflores@gmail.com

${ }^{3}$ Graduate Program in Veterinary Medicine (PPGMV), Universidade Federal de Santa Maria (UFSM), Av. Roraima 1000, Santa Maria, RS 97105-900, Brazil.

${ }^{4}$ Laboratório de Virologia, Universidade Federal do Pampa (Unipampa), Rodovia BR-472 Km 585, Uruguaiana, RS 97501-970, Brazil.
}

úbere e tetos de vacas. Pouco se sabe sobre a patogênese do BoHV-2, dificultando o desenvolvimento de medicamentos terapêuticos e vacinas. Este estudo investigou a patogênese do BoHV-2 em bezerros após a inoculação por diferentes

\footnotetext{
${ }^{5}$ Laboratório de Bacteriologia, Departamento de Medicina Veterinária Preventiva, Universidade Federal de Santa Maria (UFSM), Av. Roraima 1000, Prédio 63C, Santa Maria, RS 97105-900, Brazil.

${ }^{6}$ Laboratório de Virologia, Universidade do Oeste de Santa Catarina (Unoesc), Rua Dirceu Giordani 696, Xanxerê, SC 89820-000, Brazil.

${ }^{7}$ Department of Population Medicine and Diagnostic Sciences, Animal Health Diagnostic Center, College of Veterinary Medicine, Cornell University, Ithaca, NY 14853, USA.
} 
vias. Bezerros soronegativos de três a quatro meses foram inoculados com BoHV-2 (107TCID50. $\left.\mathrm{mL}^{-1}\right)$ por via intramuscular (IM, $n=4$ ), por via intravenosa (IV, $n=4$ ) ou transdérmica (TD, $\mathrm{n}=4$ ) após escarificação leve e submetidos a monitoramento virológico, clínico e sorológico. Os bezerros inoculados pela via IV apresentaram aumento leve da temperatura corporal entre os dias 6 a 9 pós-inoculação (pi). A inoculação do vírus pela via TD resultou em lesões inflamatórias leves nos locais de inoculação, caracterizadas por hiperemia, pequenas vesículas, exsudação leve e formação de crostas, entre os dias 2 e 8 pi. 0 vírus ou DNA viral foi detectado por PCR nas crostas/swabs coletados de lesões de 3 de 4 animais inoculados TD do dia 2 ao 8pi. Viremia foi detectada em $3 / 4$ dos animais do grupo IM (do dia 4 ao 8pi); em 2/4 animais do grupo IV (dias 6 e 8 pi), mas não no grupo TD. Bezerros de todos os grupos inoculados soroconverteram o BoHV-2 em títulos de 4 a 64, conforme indicado por ensaios de vírus-neutralização (VN) realizados em soro coletado no dia 15pi. Administração de dexametasona (Dex) nos bezerros inoculados no dia 48pi, não resultou em reativação do vírus, como indicado pela falta de detecção de vírus no sangue e/ou nos locais de inoculação e pela ausência de aumento nos títulos de anticorpos. Estes resultados demonstraram que o BoHV-2 foi capaz de replicar eficientemente em bezerros seguindo diferentes vias de inoculação, produziu viremia após a inoculação IM e IV e não foi reativado pelo tratamento com Dex.

TERMOS DE INDEXAÇÃO: Patogênese, alfaherpesvírus bovino 2, bezerros, bovinos, infecção aguda, latência.

\section{INTRODUCTION}

Bovine alphaherpesvirus 2 - formerly bovine herpesvirus type 2 (BoHV-2) - is an enveloped, double-stranded DNA virus belonging to the family Herpesviridae, subfamily Alphaherpesvirinae, genus Simplexvirus (ICTV 2018). BoHV-2 is genetically and antigenically related to Human alphaherpesviruses 1 and 2 (HSV-1, HSV-2) (Sterz et al. 1974, Borchers et al. 1990, Ehlers et al. 1999). BoHV-2 is the agent of bovine herpetic mammillitis (BHM), a vesicular, erosive and necrotic cutaneous disease of the udder and teats of cows. The distribution and prevalence of BoHV-2 infection are poorly understood, but serologic data indicate that the virus is widespread in cattle worldwide (Rweyemamu et al. 1966, Dardiri \& Stone 1972, Gibbs \& Rweyemamu 1977).

Historically, BoHV-2infection has been described in several countries, including the United States (US) (Dardiri \& Stone 1972), Great Britain (Johnston \& Scott 1971), Brazil (Alice 1977, Campos et al. 2014), Kenya (Martin \& Gwynne 1968), Australia and Japan (Turner et al. 1974, Imai et al. 2005). In addition to the classic BHM, BoHV-2 has also been associated with a generalized nodular skin condition called pseudo-lumpy skin disease (PLSD) (Gibbs \& Rweyemamu 1977). Antibodies to BoHV-2 have been detected in wild ruminants (Plowright \& Jesset 1971) and the infection has been experimentally reproduced in goats (Westbury 1981) and sheep (Torres et al. 2009b). However, a potential role of these species in the epidemiology of BoHV-2 remains uncertain. Likewise, there is no evidence of human infection, in spite of attempts to reproduce the infection upon inoculation of volunteers (Martin et al. 1966). Large outbreaks of BoHV-2-associated cutaneous disease occurring in a 10-year-period were described in dairy breed calves in California, US (Watanabe et al. 2017). These findings suggest that, like to other simplex viruses, BoHV-2 may circulate silently in susceptible host populations, occasionally producing clinical cases or outbreaks. This behavior may also explain findings of positive BoHV-2 serology in cattle populations with no evident, or scarce, history of compatible clinical disease (Almeida et al. 2008, Torres et al. 2009b).

In spite of its long story and several decades of scattered studies, several aspects of BoHV-2 biology and pathogenesis remain obscure. The pathogenesis of acute and latent infection remains poorly understood. The few pathogenesis studies in cattle were performed two or three decades ago, using old and nowadays obsolete techniques and resources. Experimental reactivation of the infection has not been consistently demonstrated (Probert \& Povey 1975, Turner et al. 1976, Castrucci et al. 1980) and attempts to recover the virus upon explant cultures of sensory nerve ganglia have failed (Letchworth \& Carmichael 1982). In some of the studies demonstrating latency and reactivation, biases may have been introduced by inoculating the virus intravenously (Castrucci et al. 1972, Scott \& Martin 1978). Likewise, the sites in which the virus may remain latent remain unknown (Letchworth \& Carmichael 1982). Pathogenesis studies were performed in animal models, with their inherent pitfalls and restrictions (Almeida et al. 2008, Torres et al. 2009a). Thus, a better understanding of BoHV-2 pathogenesis in their natural hosts is needed.

In addition, bovine herpesviruses have been proposed as viral vector for vaccine antigen delivery (Kanekiyo et al. 2019). As such, BoHV-2 may be also a candidate viral vector for vaccine use. Therefore, the present study investigated selected aspects of the pathogenesis of BoHV-2 in calves.

\section{MATERIALS AND METHODS}

Cell culture and virus. Bovine alphaherpesvirus 2 (BoHV-2) strain New York 01 (NY01) was kindly provided by Dr. Fernando A. Osorio (Department of Veterinary and Biomedical Sciences, University of Nebraska, Lincoln, USA). All procedures of virus replication, quantitation and virus neutralizing assays (VN) were performed in CRIB cells (a MDBK-derived cell line resistant to BVDV). Cells were maintained in Eagle's minimum essential medium (MEM) (Vitrocell ${ }^{\circledR}$, Nova Campinas, São Paulo, Brazil) supplemented with $10 \%$ fetal calf serum (Vitrocell $\left.{ }^{\circledR}\right)$, penicillin (10,000 IU.mL-1), streptomycin

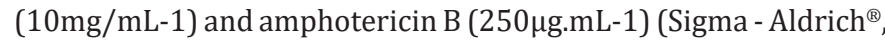
Darmstadt, Hessen, Germany). The virus inoculum consisted of the supernatant of CRIB cells infected with BoHV-2 at passage \# 12, containing $10^{7} \mathrm{TCID}_{50} \cdot \mathrm{mL}^{-1}$ (median tissue culture infectious doses).

Animal experiment. Sixteen holstein with ages ranging from 90 to 120 days, tested negative for BoHV-2 antibodies by virus neutralizing (VN) assays were used in the experiment. The animals were randomly allocated in four groups of four animals each and submitted to the following inoculation protocols: four calves were inoculated by the intramuscular route (IM group); four calves were inoculated by intravenous route (IV group); four calves were inoculated in the skin of the internal face of the left hind limb, after scarification with a needle (TD group) and application of the virus inoculum with the help of a cotton swab. Each animal was inoculated with $10^{7} \mathrm{TCID}_{50} \cdot \mathrm{mL}^{-1}$ of the virus. The four remaining animals (Control group) were inoculated with minimal essential médium (MEM) by the IM route $(n=1)$, IV route $(n=1)$ and by scarification of the skin, 
as described by the TD group $(n=2)$. The experimental groups were maintained in separated barns and given food and water ad libitum.

Experimental inoculated animals were monitored daily for local and systemic clinical signs; blood, nasal secretions and exudates of the inoculation sites were collected for virus detection. Clinical monitoring consisted of visual inspection and photographic registration of local signs (TD group); measurements of rectal temperatures, recording of appetite and alertness (all groups). Blood samples and nasal swabs were collected every two days from calves of the IM and IV groups. Nasal secretions and buffy coats were submitted to DNA extraction and PCR for the BoHV-2 genome. Swabs collected from the sites of virus inoculation (TD group) were collected daily and also submitted to PCR for BoHV-2 DNA. Serum samples were collected at days 0 and 14 pi and submitted to VN assays for BoHV-2 antibodies. Forty-eigtht days after virus inoculation, inoculated animals were submitted to dexamethasone (Dex) treatment (Azium-Merck Sharp and Dohme ${ }^{\circledR}$, Kenilworth, Nova Jersey, USA), $0.1 \mathrm{mg} / \mathrm{kg} /$ day for 5 consecutive days, and monitored thereafter for viremia, virus shedding, clinical signs and seroconversion. All procedures involving animals were approved by an institutional committee on ethics and animal welfare (CEUA-UFSM, approval number 6173221215).

Virus neutralizing assays. Virus-neutralizing (VN) assays were performed in duplicates in 96-well plates, incubating two-fold dilutions of the sera against $100-200 \mathrm{TCID}_{50} .50 \mu \mathrm{L}^{-1}$ of the virus for $1 \mathrm{~h}$, followed by addition of a suspension of CRIB cells and incubation of the plates at $37^{\circ} \mathrm{C}$ in a $\mathrm{CO}_{2}$ incubator. Readings were performed at $96 \mathrm{~h}$, by visualization of typical BoHV-2 cytopathic effect (cpe) in indicator cells. VN titers were considered as the reciprocal of the highest serum dilution that prevented the production of cpe. Sera positive and negative for BoHV-2 antibodies were used as controls in all assays.

Nucleic acid extraction and PCR. Total DNA was extracted from buffy coats, nasal secretions or cutaneous scabs/exudates by thephenol-chloroform protocol and submitted to final elution in $50 \mu \mathrm{l}$ of Tris-EDTA solution. A semi-nested PCR targeting a sequence within the BoHV-2 glycoprotein B gene was used for viral DNA detection. The first round targeted a $624 \mathrm{bp}$ sequence and used the primers F (forward) - CTCCAGCGACGATCCTAATTTC (position 6528) and R (reverse) TATGCGTTGTGCTCTGAGTG (position 7151). The second reaction targeted a $347 \mathrm{pb}$ sequence and used the same forward primers and the reverse primer CGGTGGTCTCAAGGTTGTTC (position 6874). PCR reactions were performed in a $25 \mu \mathrm{l}$ volume, using $3 \mu \mathrm{l}$ of DNA template, $0.4 \mu \mathrm{M}$ of each primer, $2 \mathrm{mM} \mathrm{MgCl}_{2}, 8 \mathrm{mM}$ of dNTPs, $1 \times$ reaction buffer, $10 \%$ of reaction dimetilsulfoxide and 1.5 unit of Taq polymerase (Life Technologies ${ }^{\circledR}$, Carlsbad, Califórnia, USA). PCR conditions were: initial denaturation $\left(95^{\circ} \mathrm{C}\right.$ for $\left.5 \mathrm{~min}\right)$, followed by 30 cycles of $95^{\circ} \mathrm{C}$ for $45 \mathrm{~s} ; 56^{\circ} \mathrm{C}$ for 30 s for primer annealing and $72^{\circ} \mathrm{C}$ for $45 \mathrm{~s}$ for primer extension; and a final extension of $7 \mathrm{~min}$ at $72^{\circ} \mathrm{C}$. Products were visualized in a $2 \%$ agarose gel, stained with Gel Red (Biotium ${ }^{\circledR}$, Fremont, California, EUA) and visualized under UV light. Control included total DNA extracted from mock-infected and BoHV-2 infected CRIB cells.

Statistical analysis. Statistical analysis was performed using the Prism software (GraphPad; 6th version). Students T-test was performed on all groups. Statistical differences between groups were considered significant at $\mathrm{P}<0.01$.

\section{RESULTS}

\section{Acute infection}

No overt systemic signs were observed in inoculated calves in the days following virus inoculation. Food intake and alertness remained unaltered upon detailed observation. The body temperature of animals of the IV group presented an increase between days 4 and 8-9pi; groups IM and TD presented a transient increase in body temperature at day $11 \mathrm{pi}$. The temperature of control calves remained within normal limits (Fig.1). Comparing to the basal temperatures, animals from group IV presented the higher variation $(\mathrm{P}<0.01)$. Temperatures returned to pre-inoculation levels at day 11-12pi and remained at those levels up to the end of the monitoring period.

Virus inoculation after skin scarification (TD) resulted in mild inflammatory lesions within the inoculation sites. The observed changes were hyperemia, small vesicles, mild exudation and scab formation, recorded between days 2 and 8pi (Fig.2). At day 8pi, only residual and slight scabs were still present. Animals inoculated with MEM presented transient hyperemia (1-2 days) and very thin scab formation along the lines of scarification (Fig.2).

Table 1 presents the results of PCR performed in total DNA extracted from swabs/scabs of cutaneous lesions (or sites of virus inoculation) of the TD group. Viral DNA was detected in material collected from lesions of 3 out of 4 animals (75\%). Virus shedding/presence was detected from day 2 to 8 pi in two animals and from day 2 to 6 pi in one calf (Table 1 ). No viral DNA was detected after day 10pi up to day 14pi, when the collection was discontinued. These results showed a transitory virus replication/detection (lasting 4 to 6 days) in the lesions associated with skin inoculation.

The presence of viral DNA as indicator of viremic spread was investigated in the blood of inoculated calves in the days following inoculation. For this, total DNA extracted from buffy coats was submitted to the same PCR described above. The results are presented in table 2 . Viral DNA was detected in the buffy coats of $3 / 4$ animals (75\%) of the IM group, from

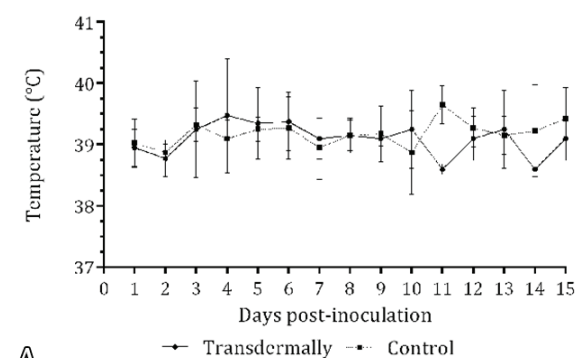

A

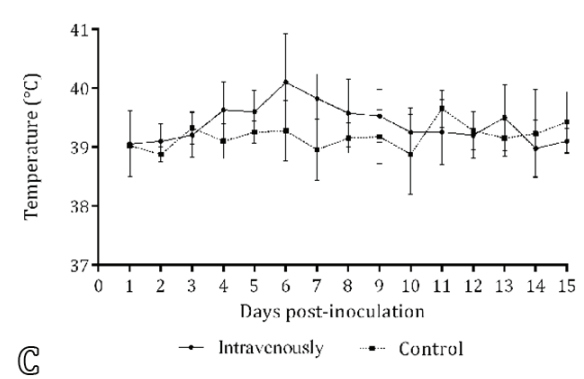

C

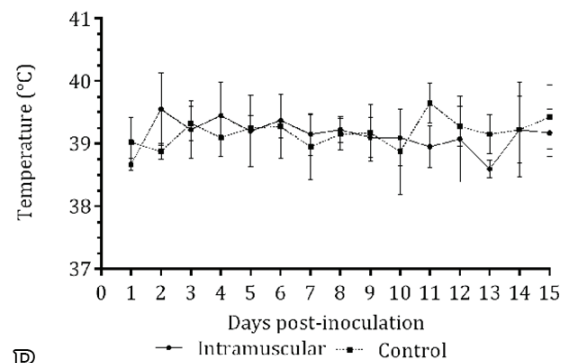

B
Days post-inoculation
- Intramuscular .... Control

alphaherpesvirus 2 (Bo

(B) intramuscular or (C) intravenous. 
day 4 to 8 pi; and in 2/4 animals (50\%) of the IV group, at days 6 and 8pi. No viral DNA was detected in the buffy coats of TD group nor in control calves (Table 2). These results demonstrated a transient viremia in calves inoculated by the IM and IV routes and no detectable viremia in the TD group.

Calves from all inoculated groups seroconverted to BoHV-2 in titers from 4 to 64 , as indicated by VN assays performed in serum samples collected at day 15pi. The mean VN titer developed by the IV group (GMT=38.05) was statistically higher than those from the IM (GMT=8) and TD (GMT=4.75) groups $(\mathrm{P}<0.01)$. Control animals remained seronegative throughout the experimental period (Table 2). The results of VN tests confirmed, indirectly, an efficient virus replication in calves of the three inoculated groups.
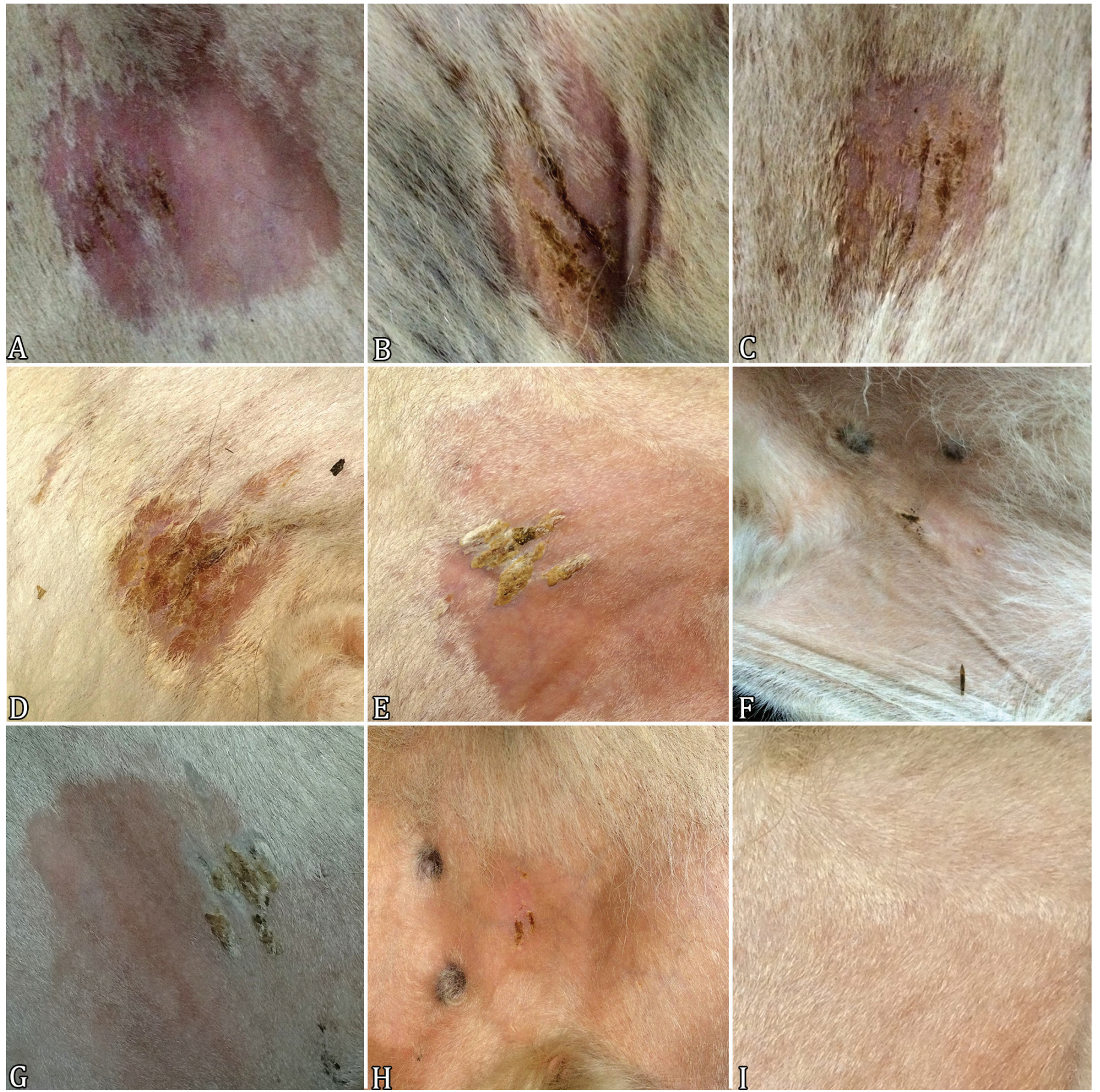

Fig 2. Skin lesions developed by calf 276 inoculated with (A, B, D, E, G, H) Bovine alphaherpesvirus 2 (BoHV-2) transdermally and (C, F, I) by a control calf inoculated with culture medium, at different days after virus inoculation. (A-B) 276 and (C) control. Days 2 and 4 pi, respectively, thin scabs and skin retraction derived from scarification. (D-E) Days 6 and 8pi. Thick, yellowish scabs and small disrupted vesicles. (F) Control. Day 8pi. A thin scab, advanced stage of healing. (G-H) 276. Days 10 and 12pi. Crust remnants, advanced stage of healing. (I) Skin completely healed (control). 


\section{Latent infection}

In attempts to reactivate latent infection, inoculated calves were submitted to a protocol of Dex administration beginning at day 48pi (five daily IM doses, following by daily examination and specimen collection). Again, food intake and alertness remained unchanged. A slight and transient increase in body temperature was observed in groups TD and IM between days 6 and 9 post-Dex (pDex) and at day $7 \mathrm{pDex}$ in group IV (Fig.3). Control calves presented a slight increase in body temperature at day $8 \mathrm{pDex}$.

No evidence of virus reactivation was observed in the inoculated calves upon Dex administration. PCRs of the buffy coats (IM, IV groups) and from swabs collected from the inoculation sites (ID group) were negative for viral DNA.

Table 1. Results of PCR performed on DNA extracted from material obtained from swabs and lesions of calves inoculated transdermally with Bovine alphaherpesvirus 2 (BoHV-2)

\begin{tabular}{cccccccccc}
\hline \multirow{2}{*}{ Animal ID } & \multicolumn{8}{c}{ Days post-inoculation } \\
\cline { 2 - 9 } & 0 & 2 & 4 & 6 & 8 & 10 & 12 & 14 \\
\hline 276 & - & + & + & + & + & - & - & - \\
280 & - & + & + & + & + & - & - & - \\
284 & - & - & - & - & - & - & - & - \\
294 & - & + & + & + & - & - & - & -
\end{tabular}

Likewise, the VN titers pre- (day 48pi) and post-Dex (day $60 \mathrm{pi}$ ) remained unaltered in most animals, or with a single dilution difference (higher or lower), demonstrating absence of re-stimulation of the immune system upon Dex treatment. Taken together, these results demonstrated lack of detectable virus reactivation.

\section{DISCUSSION}

Bovine alphaherpesvirus 2 (BoHV-2) has been a neglected virus, probably due to its limited sanitary, economic importance and rare occurrence. The scarce knowledge about its biology, molecular biology and pathogenesis has somehow hampered its use as a model for human simplex viruses and as a vector for vaccine delivery, among others. Our group has long been interested in BoHV-2 epidemiology and pathogenesis (Almeida et al. 2008, Torres et al. 2010). More recently, we have focused our interest in the use of BoHV-2 for anti-viral drug testing and for development of vaccine platforms for antigen delivery. In this sense, a better understanding of the biology of BoHV-2 in its natural host would help future developments.

Early studies on BoHV-2 focused on clinic-pathological description of clinical cases/outbreaks (Weaver et al. 1972, Castrucci et al. 1978, Castrucci et al. 1979, Woods et al. 1996, Kemp et al. 2008) and/or experimental reproduction of clinical disease in cattle (Weaver et al. 1972, Turner et al.

Table 2. Virological and serological findings in calves inoculated with Bovine alphaherpesvirus 2 (BoHV-2) by different routes

\begin{tabular}{|c|c|c|c|c|c|c|c|c|c|c|c|c|c|}
\hline \multirow{2}{*}{ Group } & \multirow{2}{*}{ Animal ID } & \multicolumn{8}{|c|}{ PCR - days post inoculation } & \multicolumn{4}{|c|}{ VN assays - days post inoculation } \\
\hline & & 0 & 2 & 4 & 6 & 8 & 10 & 12 & 14 & 0 & 15 & 48 & 60 \\
\hline \multirow[t]{4}{*}{ Intramuscular } & 274 & - & - & + & + & - & - & - & - & $<2$ & $<2$ & $<2$ & $<2$ \\
\hline & 277 & - & - & - & - & - & - & - & - & $<2$ & 4 & $<2$ & 2 \\
\hline & 281 & - & - & + & + & + & - & - & - & $<2$ & 16 & 16 & 8 \\
\hline & 282 & - & - & - & - & + & - & - & - & $<2$ & 8 & 8 & 16 \\
\hline \multirow[t]{4}{*}{ Intravenous } & 283 & - & - & - & + & + & - & - & - & $<2$ & 32 & 64 & 32 \\
\hline & 287 & - & - & - & + & + & - & - & - & $<2$ & 32 & 64 & 32 \\
\hline & 295 & - & - & - & - & - & - & - & - & $<2$ & 64 & 64 & 32 \\
\hline & 299 & - & - & - & - & - & - & - & - & $<2$ & 16 & 32 & 32 \\
\hline \multirow[t]{4}{*}{ Transdermal } & 276 & - & - & - & - & - & - & - & - & $<2$ & 8 & 4 & 8 \\
\hline & 280 & - & - & - & - & - & - & - & - & $<2$ & 4 & 4 & 2 \\
\hline & 284 & - & - & - & - & - & - & - & - & $<2$ & 4 & 2 & $<2$ \\
\hline & 294 & - & - & - & - & - & - & - & - & $<2$ & 4 & 4 & 4 \\
\hline \multirow[t]{4}{*}{ Control } & 286 & - & - & - & - & - & - & - & - & $<2$ & $<2$ & $<2$ & $<2$ \\
\hline & 289 & - & - & - & - & - & - & - & - & $<2$ & $<2$ & $<2$ & $<2$ \\
\hline & 292 & - & - & - & - & - & - & - & - & $<2$ & $<2$ & $<2$ & $<2$ \\
\hline & 293 & - & - & - & - & - & - & - & - & $<2$ & $<2$ & $<2$ & $<2$ \\
\hline
\end{tabular}
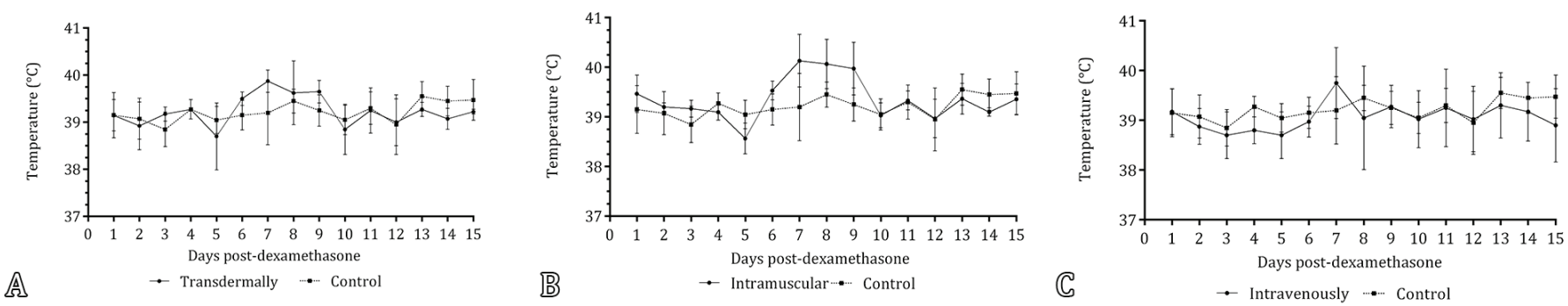

Fig.3. Mean body temperature $\left(\mathrm{T}^{\circ} \mathrm{C}\right)$ of calves inoculated with Bovine alphaherpesvirus 2 (BoHV-2) by different routes: (A) transdermal,

(B) intramuscular and (C) intravenous and submitted to dexamethasone administration at day 40pi. 
1974, Castrucci et al. 1978, Woods et al. 1996, Kemp et al. 2008) and animal models (Westbury 1981, Almeida et al. 2008, Smee \& Leonhardt 1994, Torres et al. 2009a, 2010). A few experimental studies focusing on acute disease (Castrucci et al. 1977, Castrucci et al. 1982) or latent infection Probert \& Povey (1975), Scott \& Martin (1978), Letchworth \& Carmichael (1982) introduced probably biases on data interpretation due to IV virus inoculation, an unlikely natural route of exposure. For instance, the virus tropism and systemic dissemination were investigated after IV inoculation (Castrucci et al. 1977, 1978). Against this hypothesis, several lines of evidence point out for virus penetration/transmission by direct/indirect contact (Castrucci et al. 1982). Thus, the results of some early studies should be interpreted with caution since they may not reflect the natural route of inoculation. Likewise, results from studies in animal models might not necessarily reflect the events occurring in the natural hosts.

We performed BoHV-2 inoculation though different routes for the following reasons. The TD route was chosen because it would more closely resemble the natural route of infection. Using this protocol of virus inoculation, we have successfully reproduced udder and teat lesions typical of BHM in ewes (Almeida et al. 2008). The IV route was employed trying to reproduce the virological findings of early studies which used this route (Castrucci et al.1977, Castrucci et al. 1978, Martin $\&$ Scott 1979). Finally, the IM route aimed at stimulating the events following IM administration of BoHV-2 as a vaccine vector.

In our study, viremic dissemination was observed after IM inoculation and, to a lesser extent, after IV administration. In both groups, detection of viral DNA in the blood was transient, lasting 1 to 4 days. In contrast, virus inoculation after skin scarification did not result in viremic spread in spite of virus replication and detection in local sites for 4 to 6 days (Table 1). The localized nature of cutaneous BoHV-2 replication and pathology has been previously attributed to the route of virus penetration/exposure, specific virus tropism and, additionally, to the surface temperature which may favor virus replication (Letchworth et al. 1982a). In fact, early studies have demonstrated that $\mathrm{BoHV}-2$ replicates more efficiently at lower temperatures $\left(30-3^{\circ} \mathrm{C}\right)$, comparing to replication at physiological bovine temperatures $\left(38-39^{\circ} \mathrm{C}\right.$ ) (Letchworth et al. 1982a, Letchworth \& Carmichael 1984). The preference for replication at low temperatures might also explain the higher incidence and distribution of BoHV-2 in regions of temperate climate (Letchworth \& Carmichael 1984). On the other hand, systemic viral spread has been demonstrated only after IV inoculation (Castrucci et al. 1977, 1978). In this sense, our results demonstrated that IM inoculation results in virus replication and viremic spread. These findings might be a safety concern towards the potential use of BoHV-2 as a vaccine vector for IM use. Thus, the possible consequences of BoHV-2 viremic spread upon IM administration should be properly addressed.

A major route of BoHV-2 penetration in natural infections seems to be throughout micro-lesions/abrasions in the epithelium of the udder and teats. As such, our protocol of TD inoculation aimed at mimetizing the natural events leading to virus penetration and replication. Virus inoculation after skin scarification resulted in mild inflammatory lesions characterized by hyperemia, small vesicles, mild exudation and scab formation between days 2 and 8pi (Fig.2). Contrasting with some previous studies (Gibbs et al. 1973, Letchworth et al. 1982b), no classical BHM lesions were reproduced upon skin inoculation. In a previous study, we reproduced similar BHM lesions in the udder and teats of ewes experimentally inoculated (Almeida et al 2008). The differences in the clinical outcome may attributed to the nature of the skin epithelium of the hind limbs versus udder/teats and/or to the procedure of virus inoculation. In any case, virus replication and mild, transient cutaneous lesions were produced upon TD virus inoculation. Virus replication seemed to be restricted to the cutaneous surface of the inoculation sites since viremic spread was not detected.

Although BoHV-2 is known to establish latent infections, recovery of infectious virus and/or demonstration of virus reactivation after corticosteroid treatment has not been consistently achieved either in natural or experimental infections (Probert \& Povey 1975, Castrucci et al 1980, Letchworth \& Carmichael 1982). A few attempts were successful in recovering virus and/or demonstrating reactivation upon corticosteroid treatment, yet mainly in animals inoculated by the IV route (Scott \& Martin 1978, Martin \& Scott 1979, Castrucci et al.1982), which is unlikely to be the natural route of infection. Otherwise, latency, reactivation and colonizing of sensory nerve ganglia with latent DNA have been demonstrated in experimental models (Almeida et al. 2008, Torres et al. 2009a). In our study, no virus shedding or seroconversion were observed upon Dex administration, in spite of virus replication in the sites of virus inoculation and presence of the virus in blood during acute infection. These results corroborate previous studies which failed in demonstrating virus reactivation in BoHV-2-infected cattle (Probert \& Povey 1975, Castrucci et al 1980, Letchworth \& Carmichael 1982). From the vaccine perspective, the failure/ lack of reactivation would be a highly desirable property of a candidate vaccine viral vector. Unfortunately, we did not keep the calves for investigating the sites of latent infection upon the different routes of exposure.

Nearly 50 years after the initial identification of BoHV-2 as the agent of BHM (Gibbs et al. 1973) and, subsequently, the demonstration of its relationship with human simplex viruses (Snowden et al 1985, Castrucci et al. 1990, Ehlers et al. 1999), the pathogenesis of BoHV-2 in cattle is still poorly understood. Thus, our data contributes for the overall knowledge on the biology and pathogenesis of this simplex virus. Regardless its restricted sanitary/economic relevance, this bovine virus should be looked at from different perspectives. First, BoHV2 infection offers a unique opportunity to study selected aspects the molecular biology, pathogenesis and immunology of a simplex virus in their natural host. HSV-1 and HSV-2 are among the most studied human viruses, yet the studies in vivo are largely restricted to animal models (Kollias et al. 2015). Thus, studying the biology of a simplex virus in its natural host may particularly attractive/fascinating since it may provide new and more realistic insights in the virus-host interactions. Second, the biological and genetic similarity of BoHV-2 with human simplex viruses may be exploited for the research and development of pharmaceuticals and vaccines as well. In this sense, BoHV-2 has been proposed as a potential target/model for the development of anti-herpetic drugs (Field et al. 2006, Dezengrini et al. 2010, Torres et al. 
2010). Third, animal herpesviruses have been long proposed as potential platforms for vaccine delivery and a number of current animal vaccines are based on herpesvirus vectors (Verma \& Weitzman 2005, Kanekiyo et al. 2019). Thus, more than a cattle pathogen of questionable clinical relevance, BoHV-2 may represent an attractive alternative to study the interactions of simplex viruses with their hosts, for research/ development of anti-herpetic drugs and veterinary vaccines.

\section{CONCLUSION}

Inoculation of BoHV-2 in calves by different routes results in virus replication, yet viremic spread occurs after intramuscular or intravenous inoculation but not after transdermal inoculatio.

Acknowledgements.- The authors thank the "Conselho Nacional de Desenvolvimento Científico e Tecnológico" (CNPq) for the scholarships. Bruna Portolan Amaral received PhD's Scholarship, Eduardo F. Flores (process 301414/2016) and Rudi Weiblen (process 305867/2018-0) were supported by CNPq research fellowships. This study was financed in part by the "Coordenação de Aperfeiçoamento de Pessoal de Nível Superior" (CAPES), Brasil - Finance code 001. BPA is graduate students of the "Programa de Pós-graduação em Medicina Veterinária" (PGMV-UFSM).

Conflict of interest statement.- The authors have no conflicting of interest.

\section{REFERENCES}

Alice F.J. 1977. Isolamento do vírus da mamilite herpética bovina no Brasil. Revta Microbiol. 8(1):9-15.

Almeida S.R., Diel D.G., Rissi D.R., Weiblen R. \& Flores E.F. 2008. Pathological clinical characterization of acute mamillitis in lactating sheep experimentally infected with Bovine herpesvirus 2. Pesq. Vet. Bras. 28(1):87-94. <http:// dx.doi.org/10.1590/S0100-736X2008000100014>

Borchers K., Özel M., Pauli G., Gelderblom H.R. \& Ludwig H. 1990. Conserved epitopes of simian herpesvirus SA 8 and Bovine herpesvirus type 2. Arch. Virol. 111(1/2):1-14. <http://dx.doi.org/10.1007/BF01310501>

Campos F.S., Franco A.C., Oliveira M.T., Firpo R., Strelczuk G., Fontoura F.E., Kulmann M.I., Maidana S, Romera S.A., Spilki F.R., Silva A.D., Hübner S.O. \& Roehe P.M. 2014. Detection of bovine herpesvirus 2 and bovine herpesvirus 4 DNA in trigeminal ganglia of naturally infected cattle by polymerase chain reaction. Vet. Microbiol. 171(1/2):182-188. <http://dx.doi.org/10.1016/j. vetmic.2014.03.012><PMid:24725448>

Castrucci G., Ferrari M., Frigeri F. \& Aldrovandi V. 1990. A further study on relationships between herpes simplex virus and Bovid herpesvirus-2. Microbiologica 13(2):101-107. <PMid:2161993>

Castrucci G., Ferrari M., Frigeri F., Ranucci S., Cilli V., Tesei B. \& Rampichini L. 1982. Reactivation in calves of bovid herpesvirus 2 latent infection. Arch. Virol. 72(1/2):75-81. <http://dx.doi.org/10.1007/BF01314452> $<$ PMid:6285866>

Castrucci G., Frigeri F., Cilli V., Rampichini L., Ranucci S. \& Poli G. 1978. Distribution of bovid herpesvirus 2 in calves inoculated intravenously. Am. J. Vet. Res. 39(6):943-947. <PMid:208435>

Castrucci G., Frigeri F., Cilli V., Rampichini L., Ranucci S. \& Poli G. 1979. A study of bovid herpesvirus 2 infection in calves inoculated intradermally or intranasally. Comp. Immun. Microbiol. Infect. Dis. 1(4):277-283. <http:// dx.doi.org/10.1016/0147-9571(79)90029-8><PMid:233779>

Castrucci G., Frigeri F., Cilli V., Tesei B., Arush A.M., Pedini B., Ranucci S. \& Rampichini L. 1980. Attempts to reactivate bovid herpesvirus 2 in experimentally infected calves. Am. J. Vet. Res. 41(11):1890-1893. <PMid:6259974>
Castrucci G., Pedini B. \& Arancia G. 1972. Characterisation of a viral agent resembling bovine herpes mammillitis virus. Vet. Rec. 90(12):325-335. <http://dx.doi.org/10.1136/vr.90.12.325> <PMid:4339363>

Castrucci G., Rampichini L., Frigeri F., Ranucci S. \& Cilli V. 1977. Preliminary studies on the diffusion of bovid herpesvirus 2 in experimentally infected calves. Folia Vet. Lat. 7(3):243-251. <PMid:207630>

Dardiri A.H. \& Stone S.S. 1972. Serologic evidence of dermophatic bovine herpesvirus infection of cattle in the United States of America. Proc. Ann. Meet. U. S. Anim. Health. Assoc. 76(1):156-171.

Dezengrini R., Silva S.C., Weiss M., Kreutz L. C., Weiblen R. \& Flores E.F. 2010. Atividade de três drogas antivirais sobre os herpesvírus bovino tipos 1, 2 e 5 em cultivo celular. Pesq. Vet. Bras. 30(10):855-860. <http://dx.doi. org/10.1590/S0100-736X2010001000008>

Ehlers B., Goltz M., Ejercito M.P., Dasika G.P. \& Lechtworth G.J. 1999. Bovine herpesvirus type 2 is closely related to the primate alphaherpesviruses. Virus Genes 19(3):197-203. <http://dx.doi.org/10.1023/A:1008184630066> <PMid:10595411>

Field H.J., Biswas S., Mohammad I.T. 2006. Herpesvirus latency and therapy, from a veterinary perspective. Antiviral Res. 71(2/3):127-133. <http:// dx.doi.org/10.1016/j.antiviral.2006.03.018><PMid:16843537>

Gibbs E.P \& Rweyemamu M.M. 1977. Bovine herpesviruses. Part II. Bovine herpesviruses 2 and 3. Vet. Bull. 47(5):411-425.

Gibbs E.P., Johnson R.H. \& Osborne A.D. 1973. Experimental studies of the epidemiology of bovine herpes mammillitis. Res. Vet. Sci. 14(2):139-144. <PMid:4375832>

ICTV 2018. International Committee on Taxonomy of Viruses. Available at <https://talk.ictvonline.org/taxonomy/> Accessed Jul. 25, 2019.

Imai K., Ishihara R. \& Nishimori T. 2005. First demonstration of bovine herpesvirus 2 infection among cattle by neutralization test in Japan. J. Vet. Med. Sci. 67(3):317-320. <http://dx.doi.org/10.1292/jvms.67.317> <PMid:15805737>

Johnston W.S., Wray C. \& Scott J.A. 1971. An outbreak of bovine herpes mammillitis in a suckler herd. Vet. Rec. 88(14):372. <http://dx.doi. org/10.1136/vr.88.14.372-a><PMid:4324525>

Kanekiyo M., Ellis D. \& King N.P. 2019. New vaccine design and delivery technologies. J. Infect. Dis. 219(supl.1):S88-S96. <http://dx.doi.org/10.1093/ infdis/jiy745><PMid:30715361>

Kemp R., Hollman A. \& Nettleton P.F. 2008. Atypical bovine herpes mammillitis affecting cows and calves. Vet. Rec. 163(4):119-121. <http://dx.doi. org/10.1136/vr.163.4.119><PMid:18660522>

Kollias C.M., Huneke R.B., Wigdahl B. \& Jennings S.R. 2015. Animal models of herpes simplex virus immunity and pathogenesis. J. Neurovirol. 21(1):823. <http://dx.doi.org/10.1007/s13365-014-0302-2><PMid:25388226>

Letchworth G.J. \& Carmichael L.E. 1982. Bovid herpesvirus 2 latency: failure to recover virus from sensory nerve ganglia. Can. J. Comp. Med. 46(1):76-79. <PMid:6280823>

Letchworth G.J. \& Carmichael L.E. 1984. Local tissue temperature: a critical factor in the pathogenesis of bovid herpesvirus 2. Infect. Immun. 43(3):1072-1079. <PMid:6199299>

Letchworth G.J., Carmichael L.E. \& Greisen H.A. 1982a. Sensitivity of bovid herpesvirus 2 replication to temperatures found in the natural host. Arch. Virol. 73(3/4):273-286. <http://dx.doi.org/10.1007/BF01318081> <PMid:6293416>

Letchworth G.J., Carmichael L.E. \& Lein D.H. 1982b. Bovid herpesvirus 2: natural spread among breeding bulls. Cornell Vet. 72(2):200-210.<PMid:6282532>

Martin W.B, Martin B., Hay D. \& Lauder I.M. 1966. Bovine ulcerative mammillitis caused by a herpesvirus. Vet. Rec. 78(14):494-4977. <http://dx.doi.org/10.1136/vr.78.14.494> <PMid:4289617> 
Martin W.B. \& Gwynne M. 1968. Antibodies to the group II lumpy skin disease virus in the sera of cattle in Kenya. Bull. Epizoot. Dis. Afr. 16(2):217-222. <PMid:4303239>

Martin W.B. \& Scott F.M.M. 1979. Latent infection of cattle with bovid herpesvirus 2. Arch. Virol. 60(1):51-58. <http://dx.doi.org/10.1007/ BF01318097><PMid:226033>

Plowright W. \& Jesset D.M. 1971. Investigation of Allerton-type herpesvirus infection in East African game animals and cattle. J. Hyg. 69(2):209-222. <http://dx.doi.org/10.1017/S0022172400021446>

Probert M. \& Povey R.C. 1975. Experimental studies concerning the possibility of a latent carrier state in bovine herpes mammillitis (BHM). Arch. Virol. 48(1):29-38. <http://dx.doi.org/10.1007/BF01320563><PMid:167683>

Rweyemamu M.M., Johnson R.H. \& Tutt J.B. 1966. Some observations on herpesvirus mammillitis of bovine animals. Vet. Rec. 79(25)810-811. <http://dx.doi.org/10.1136/vr.79.25.810> <PMid:4292108>

Scott F.M. \& Martin W.B. 1978. Antibody to bovid herpesvirus 2 in the sera from cattle in the Netherlands. Vet. Rec. 102(21):464. <http://dx.doi. org/10.1136/vr.102.21.464><PMid:208225>

Smee D.F. \& Leonhardt J.A. 1994. Vaccination against bovine herpes mammillitis virus infections in guinea pigs. Intervirology 37(1):20-24. <http://dx.doi. org/10.1159/000150351><PMid:7928285>

Snowden B.W., Kinchington P.R., Powelland K.L. \& Halliburton I.W. 1985. Antigenic and biochemical analysis of gB of herpes simplex virus type 1 and type 2 and of cross-reacting glycoproteins induced by bovine mammillitis virus and equine herpesvirus type 1. J. Gen. Virol. 66(Pt2):231-247. <http://dx.doi.org/10.1099/0022-1317-66-2-231><PMid:2981966>

Sterz H., Ludwig H. \& Rott R. 1974. Immunologic and genetic relationship between herpes simplex virus and bovine herpes mammillitis virus. Intervirology 2(1):1-13. <http://dx.doi.org/10.1159/000149398> <PMid:4362992>

Torres F.D., Almeida S.R., Silva M.S., Weiblen R. \& Flores E.F. 2009a. Distribution of latent bovine herpesvirus 2 DNA in tissues of experimentally infected sheep. Vet. Sci. 87(1):161-166. <http://dx.doi.org/10.1016/j.rvsc.2008.12.003>
Torres F.D., Bernardes L.M, Weiblen R. \& Flores E.F. 2009b. Prevalence of antibodies against herpetic mamillitis virus in cattle from Rio Grande do Sul, Brazil. Ciência Rural 39(6):1901-1904.<http://dx.doi.org/10.1590/ S0103-84782009005000116>

Torres F.D., Cargnelutti J.F., Masuda E.K., Weiblen R. \& Flores E.F. 2010. Acute and latent infection by bovine herpesvirus type 2 in a guinea pig model. Microb. Pathog. 48(2):69-73. <http://dx.doi.org/10.1016/j. micpath.2009.11.003><PMid:19931373>

Turner A.J., Kovedsy L. \& Morgan I.R. 1976. Isolation and characterization of bovine herpesvirus 2 mammillitis virus and its pathogenicity for cattle. Aust. Vet. J. 52(4):166-169. <http://dx.doi.org/10.1111/j.1751-0813.1976. tb09462.x><PMid:180955>

Turner A.J., Morgan I.R., Sykes W.E. \& Nicholls W.A. 1974. Isolation of bovine herpes mammillitis virus from dairy cattle in Victoria. Aust. Vet. J. 50(12):578-579. <http://dx.doi.org/10.1111/j.1751-0813.1974.tb14095.x> $<$ PMid:4458653>

Verma I.M. \& Weitzman M.D. 2005 Gene therapy: twenty-firstcentury medicine. Annual Rev. Biochem. 74:711-738.

Watanabe T.T.N., Moeller R.B., Crossley M. \& Blanchard P.C. 2017. Outbreaks of bovine herpesvirus 2 infections in calves causing ear and facial skin lesions. J. Vet. Diagn. Invest. 29(5):686-690. <http://dx.doi.org/10.1177/1040638717704480><PMid:28423989>

Weaver L.D., Dellers R.W \& Dardiri A.H. 1972. Bovine herpes mammillitis in New York. J. Am. Vet. Med. Assoc. 160(12):1643-1644. <PMid:4338269>

Westbury H.A. 1981. Infection of sheep and goats with bovid herpesvirus 2. Res. Vet. Sci. 31(3):353-357. <http://dx.doi.org/10.1016/S00345288(18)32471-8>

Woods J.A., Herring J.A., Nettleton P.F., Kreuger N., Scott F.M. \& Reid H.W. 1996. Isolation of bovine herpesvirus-2 (BHV-2) from a case of pseudo-lumpy skin disease in the United Kingdom. Vet. Rec. 138(5):113-114. <http:// dx.doi.org/10.1136/vr.138.5.113><PMid:8650906> 